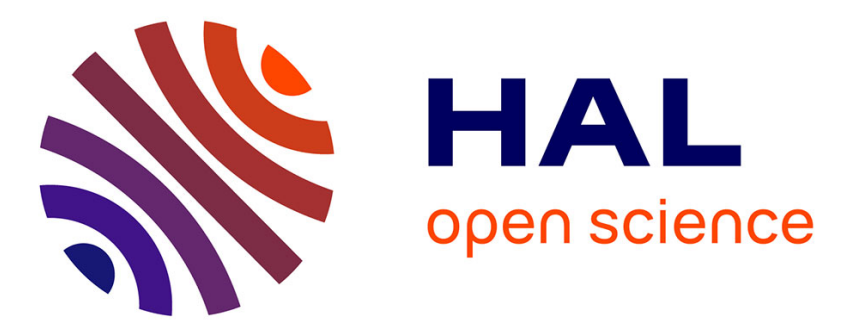

\title{
NMR chemical shift backbone assignment of the viral protein P1 encoded by the African Rice Yellow Mottle Virus
}

Yinshan Yang, Vianney Poignavent, François-Xavier Gillet, Florence Vignols, Héléne Démèné

\section{To cite this version:}

Yinshan Yang, Vianney Poignavent, François-Xavier Gillet, Florence Vignols, Héléne Démèné. NMR chemical shift backbone assignment of the viral protein P1 encoded by the African Rice Yellow Mottle Virus. Biomolecular NMR Assignments, 2019, 13 (2), pp.345-348. 10.1007/s12104-019-09903-z . hal02322880

\section{HAL Id: hal-02322880 \\ https://hal.science/hal-02322880}

Submitted on 28 Nov 2019

HAL is a multi-disciplinary open access archive for the deposit and dissemination of scientific research documents, whether they are published or not. The documents may come from teaching and research institutions in France or abroad, or from public or private research centers.
L'archive ouverte pluridisciplinaire HAL, est destinée au dépôt et à la diffusion de documents scientifiques de niveau recherche, publiés ou non, émanant des établissements d'enseignement et de recherche français ou étrangers, des laboratoires publics ou privés. 
NMR chemical shift backbone assignment of the viral protein P1 encoded by the African Rice Yellow Mottle Virus.

Yinshan Yang ${ }^{1, *}$, Vianney Poignavent ${ }^{2, \neq, *}$, François-Xavier Gillet ${ }^{2, \pm}$, Florence Vignols $^{2,3}$ and Hélène Déméné ${ }^{1}$

${ }^{1}$ Centre de Biochimie Structurale (CBS), INSERM, CNRS, Univ Montpellier, France.

2 IRD, CIRAD, Univ Montpellier, Interactions Plantes Microorganismes et Environnement (IPME), Montpellier, France.

${ }^{3}$ Laboratoire BPMP, CNRS, INRA, SupAGRO, Univ de Montpellier, Montpellier-France

${ }^{\ddagger}$ Current address: Centre National de la Recherche Scientifique, Institut de Biologie Moléculaire des Plantes, Université de Strasbourg, Strasbourg, France

${ }^{ \pm}$Current address: Laboratoire de Physiologie Cellulaire et Végétale, Institut de Biosciences et Biotechnologies de Grenoble, CNRS, CEA, INRA, Université Grenoble Alpes, Grenoble, France

*These authors contributed equally to the work

\section{Corresponding authors:}

Hélène Déméné and Florence Vignols

Helene.demene@cbs.cnrs.fr

+33(0) 467417701

Author contributions: FV and HD designed the study; VP and FXG prepared protein samples; YY and HD analyzed the data; YY, FV and H. wrote the paper.

\section{Acknowledgments}

The CBS is a member of the French Infrastructure for Integrated Structural Biology (FRISBI), a French infrastructure supported by the National Research Agency (ANR-10-INBS-05) and is a GIS-IBIsA platform. V. P. and F-X. G. were awarded with PhD-MESR Internships from the French Ministry of Education and Research. 


\section{Abstract}

RNA silencing describes a pan-eukaryotic pathway of gene regulation where doubled stranded RNA are processed by the RNAse III enzyme Dicer or homologs. In particular, plants use it as a way to defend themselves against pathogen invasions. In turn, to evade the plant immune response, viruses have developed anti-RNA silencing mechanisms. They may indeed code for proteins called "viral suppressor of RNA silencing" which block the degrading of viral genomic or messenger RNA by the plant. The Rice Mottle Virus is an African virus of the sobemovirus family, which attacks the most productive rice varieties cultivated on this continent. It encodes P1, a cysteine-rich protein described as a potential RNA silencing suppressor. P1 is a 157 amino-acid long protein, characterized by a high propensity to aggregate concomitant with a limited stability with time in the conditions used in structural studies. To overcome this problem, shorter fragments were also studied. This strategy enabled the assignment of more than $90 \%$ backbone resonances of P1. This assignment should set the base of future NMR investigation of the protein structure and of its interactions with rice cellular partners.

Keywords: RNA silencing; viral suppressor; cysteine rich; RYMV; P1; sobemovirus.

Abbreviation: RYMV, Rice Yellow Mottle Virus; RNA -Induced Silencing Complex, RISC; siRNA, Small Interfering RNA; VSR, virus silencing repressor.

\section{Biological context.}

Rice occupies a central place in the diet of many people in Africa and Asia. Rapid population growth and food habit changes result in an increasing demand, while the rice is very susceptible to pathogen attack. Among these is the Rice Yellow Mottle Virus (RYMV) in the African continent, the infection thereof generates crop losses ranging from 20 to $100 \%$. Like many other plants when confronted with pathogens, rice has evolved an immunity response under the form of viral silencing. Viral silencing represents an essential defense mechanism in plants (Ding and Voinnet, 2007). In short, plants can initiate the degradation of viral double stranded RNA, either genomic or messenger, by processing them with Dicer-like RNAses III into Small Interfering RNAs (siRNAS). Those are recruited in the multi subunit RNA-induced Silencing complex (RISC), which targets them to nuclear or cellular viral RNA for destruction. To counteract host RNAi antiviral defense, viruses from almost all plant virus genera (and also from some animal viruses) encode viral suppressors of RNA silencing (VSRs) which inhibit key steps of the cellular siRNA system 
(Song et al., 2011). They are often multifunctional and play also important roles in viral replication, coating, movement, and pathogenesis. We and others have proposed that the P1 protein of RYMV belongs to this class based on its importance for viral particle spread in rice (Siré et al., 2008) and on its ability to counteract GFP silencing in a plant reporter system (Voinnet et al., 1999).

The $\mathrm{P} 1$ protein is a 157 amino acid long protein, characterized by the presence of numerous cysteines (7) and histidines (6). Biochemical analyses have already revealed important properties of P1, including its capacity to bind two zinc atoms (Gillet et al., 2013). Further structural analyses would help in deciphering how P1 molecular features support its potential functions. However, the protein is insoluble when produced in a culture medium with a zinc concentration below $100 \mu \mathrm{M}$ (Gillet et al., 2013) and its structure has never been reported. As a first step towards solving the P1 solution structure and investigating its potential interactions with rice cellular components (proteins or nucleic acids), we report here its sequence specific backbone and some side chain assignments.

\section{Methods and experiments}

\section{Protein production and purification}

Construction of P1 clones has been previously described (Gillet et al., 2013). Full-length P1 (here termed FL $\mathrm{P} 1$ ), and its truncations P1_1-100 and P1_102-157 (comprising the segment from Met1 to Gln100 and Arg102 to Phe157, respectively) were expressed in E. coli BL21 (DE3) cells using M9 minimal medium supplemented with $1 \mathrm{~g} / \mathrm{L}^{15} \mathrm{NH}_{4} \mathrm{Cl}, 2 \mathrm{~g} / \mathrm{L}^{-1}{ }^{13} \mathrm{C}$-D-glucose, $1 \mathrm{mg} / \mathrm{L}$ thiamine and biotin and $450 \mu \mathrm{M} / \mathrm{L} \mathrm{ZnSO}_{4}$ at $37^{\circ} \mathrm{C}$. Expression was induced by addition of $0.5 \mathrm{mM}$ isopropyl- $\beta$-D-thiogalactopyranoside (IPTG) when an $\mathrm{OD}_{600} 0.6$ was reached. Cells were then subjected to a thermal shock for 2 hours at $6^{\circ} \mathrm{C}$, before further induction during five hours at $30^{\circ} \mathrm{C}$ for FL P1 and $20^{\circ} \mathrm{C}$ for P1 P1_1-100 and P1_102-157. With this protocol, P1_1-100 and P1_102-157 were produced as soluble proteins whereas FL P1 accumulated as inclusion bodies. Proteins were then purified as described in (Gillet et al., 2013), except that lysis buffer (LyB $50 \mathrm{mM}$ Tris $\mathrm{pH}$ 8, $150 \mathrm{mM} \mathrm{NaCl}, 1 \mathrm{mM}$ Zn, $1 \mathrm{mM}$ DTT) for FL P1 contained $6 \mathrm{M}$ urea to dissolve the inclusion bodies. After lysis by sonication (and dialysis against 2 L of LysB for FL P1), BL21 supernatant was loaded onto $1 \mathrm{~mL}$ of Q-Sepharose Fast Flow pre-equilibrated with buffer A (50 mM Tris-HCl, pH 8.0, 1 mM DTT). P1 constructs were eluted with buffer B (buffer $\mathrm{A}+1 \mathrm{M} \mathrm{NaCl}$ ). The $\mathrm{Zn}^{2+}$ content of eluted 
fractions was estimated by the photometric monitoring of $\mathrm{Zn}^{2+}$ release induced by 4-(2-pyridylazo) resorcinol (PAR) which complexes zinc (Gillet et al., 2013). Fractions where a maximal amount of Zn was present, were pooled, dialyzed against buffer A, and reloaded onto the Q-Sepharose Column. The repeat of this step was essential to obtain a clear separation of the different redox forms. Elution fractions containing P1 bound to the maximal amount of $\mathrm{Zn}^{2+}$, were again pooled and loaded into a Superdex 75 Hiload 26/60 column (GE Healthcare) equilibrated with buffer C (25 mM Tris-HCl, pH 7.5, $200 \mathrm{mM} \mathrm{NaCl}, 1 \mathrm{mM}$ DTT, and $500 \mu \mathrm{M}$ $\left.\mathrm{ZnSO}_{4}\right)$. The purified proteins were vaccuum concentrated and kept at $4{ }^{\circ} \mathrm{C}$ until use. Just before their use for NMR, the buffer was exchanged by dialysis against $100 \mathrm{mM} \mathrm{NaCl}, 60 \mathrm{mM} \mathrm{Na}_{2} \mathrm{SO}_{4}, \mathrm{pH} 8,500 \mu \mathrm{M} \mathrm{ZnSO}_{4}, 1$ mM DTT as stability studies by thermal shift assay showed that sodium sulfate has a net stabilizing effect.

\section{NMR spectra}

All NMR experiments were performed at $300 \mathrm{~K}$ on a Bruker Avance III spectrometer (Bruker, Rheinstetten, Germany) operating at ${ }^{1} \mathrm{H}$ frequency of $699.97 \mathrm{MHz}$, using a $5 \mathrm{~mm}$ cryogenic $\mathrm{H} / \mathrm{C} / \mathrm{N} / \mathrm{D}$ probe with Z-axis gradient. Proton chemical shifts were referenced with respect to DSS and the frequency ratios of $15 \mathrm{~N} / \mathrm{l} H=$ 0.101329118 and ${ }^{13} \mathrm{C} /{ }^{1} \mathrm{H}=0.251449530$ (Wishart et al. 1995). Assignment of the spectrum of $\mathrm{P} 1$ was carried out using a dissection approach. NMR spectra were collected for the full-length P1, but also for the shorter proteins P1_1-101, and P1_102-157. These two fragments were chosen on the basis on our previous study and on ongoing work, which characterized them as likely to contain a zinc finger each (Gillet et al., 2013). Protein concentration was $200 \mu \mathrm{M}$ (P1_1-100 and FL P1) and 2 mM (P1_102-157). Initial sequential backbone assignments were obtained with data from 3D ${ }^{15} \mathrm{~N}$-edited TOCSY-HSQC, NOESY-HSQC and 2D ${ }^{1} \mathrm{H}-{ }^{1} \mathrm{H}$ NOESY experiments for P1_1-100 and P1_102-157. These sequential ${ }^{1} \mathrm{H}$ and ${ }^{15} \mathrm{~N}$ assignments were assessed and extended to ${ }^{13} \mathrm{C}$ with 3D HNCA, HNCACB, CBCA(CO) NH, $(\mathrm{H}) \mathrm{CCH}-\mathrm{TOCSY}$ and HNCO for FL P1. Gifa was used for NMR data processing (Pons et al., 1996) and NMRView for subsequent analysis (Johnson and Blevins, 1994)

\section{NMR assignment and deposition}

FL P1 contains 157 amino acids encompassing 5 prolines. Its behaviour in solution was characterized by a 
poor solubility and a high propensity to aggregate within hours. Furthermore, the best determined solubility and stability conditions required a high ionic force, greater than $200 \mathrm{mM}$, and a high $\mathrm{pH}(>=7.5)$. These conditions are known to diminish the sensitivity of NMR experiments, in particular those where the amide proton is detected during acquisition. Even in these optimized conditions, we observed an apparent loss of sensitivity of $30 \%-60 \%$ within 3 days, depending on the preparation, presumably because of protein aggregation. Most of the missing resonances belong to contiguous segments of the N-terminal part of P1: 12$13,15-16,32-34,61-68$, suggesting that the concerned segments are exposed to solvent or subjected to conformational exchange. For the C-terminal segment, only Ser131 and Gly147 could not be assigned. For Ala16, even if the $\mathrm{N}$ and $\mathrm{HN}$ resonances could not be retrieved, we were able to assign its $\mathrm{C} \alpha$ and $\mathrm{C} \beta$ carbon resonances on the HCCH-TOCSY experiment, after all other alanine spin systems were assigned. The lowsignal/over noise ratio precluded unambiguous further assignment. Altogether, these results allowed us to assign $92 \%$ of N, HN, Ha, C, C $\alpha$ and $\mathrm{C} \beta$ resonances (fig. 1). This percentage increases to $94.6 \%$ for the $\mathrm{HN}$ and $\mathrm{N}$ resonances, i.e. 142 backbone cross-peaks could be assigned on the ${ }^{1} \mathrm{H}-{ }^{15} \mathrm{~N}$ HSQC spectrum, of the 150 expected (considering the presence of 5 prolines and the absence of cross-peak for the first residue). In addition, all amide $15 \mathrm{~N}$ and $\mathrm{HN}$ resonances of the $6 \mathrm{Gln}$ and Asn side chains could be assigned. Chemical shifts were analysed using TALOS-N to identify regions of secondary structure (Shen and Bax, 2013). According to TALOS-N, the protein has 5 beta strands and 1 small helix in the $\mathrm{N}$-terminal part, whereas the C-terminal part harbors a long helix (from residue 96 to 126) (Figure 2). Our NMR study of shifts of P1 will enable the investigation of its interaction with partners, in particular small RNAs. In future, determination of the structure of P1 and characterization of its dynamics will shed a new light on the three-dimensional properties of this domain and its numerous functions.

The chemical shift assignments have been deposited in the BioMagResBank (http://www.bmrb.wisc.edu) under the 27880 accession number.

\section{Figure caption}




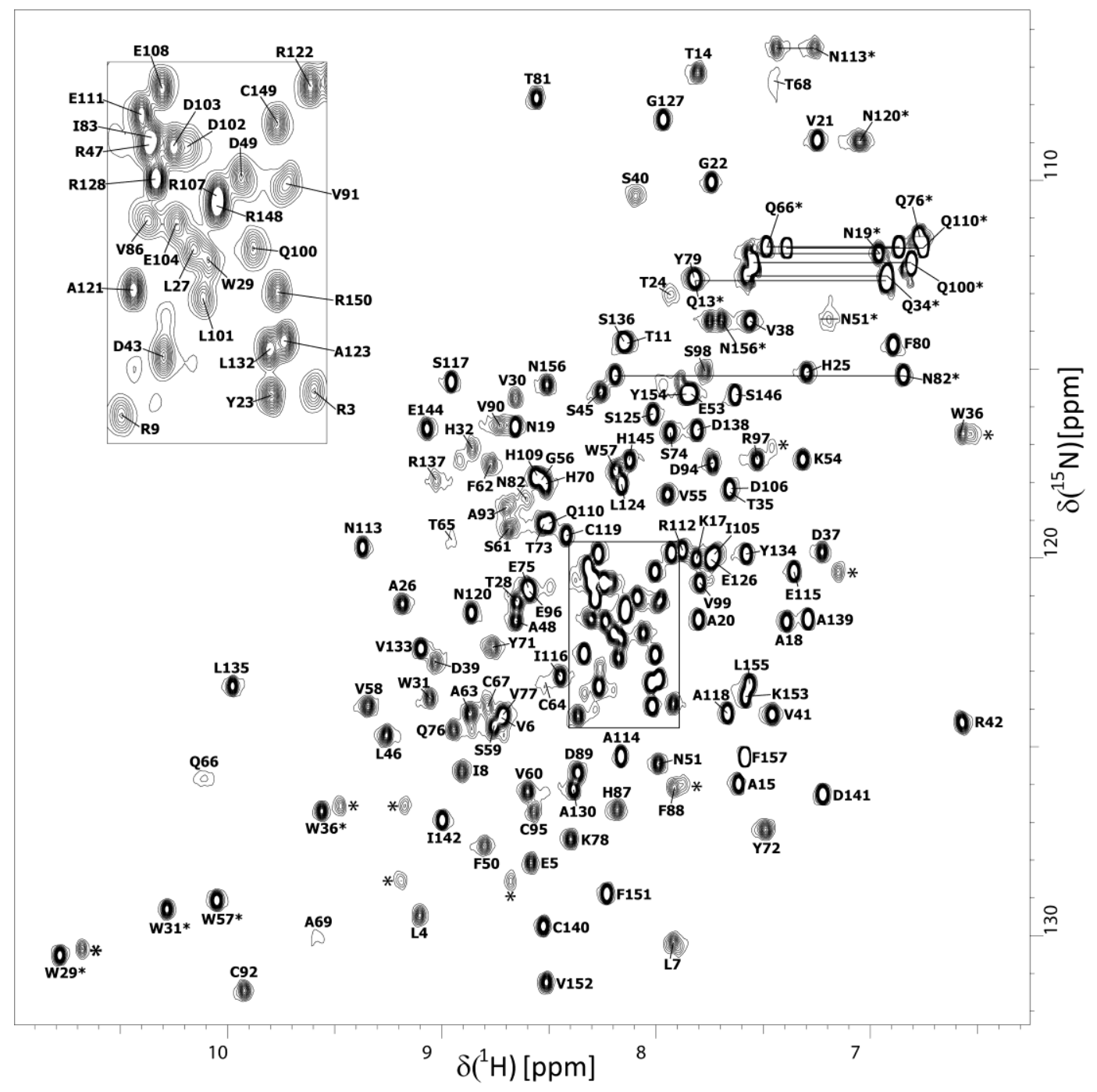

Fig. 1: 2D ${ }^{1} \mathrm{H}^{15 \mathrm{~N}} \mathrm{HSQC}$ spectrum of $200 \mu \mathrm{M}$ sample of ${ }^{15} \mathrm{~N}$-labeled $\mathrm{P} 1$ in $100 \mathrm{mM} \mathrm{NaCl}, 60 \mathrm{mM} \mathrm{Na}_{2} \mathrm{So}_{4}, 50$ $\mathrm{mM}$ Tris buffer, $\mathrm{pH} 8$ at $300 \mathrm{~K}$. Each backbone amide resonance is labeled with the amino acid type (oneletter code) and the number in the sequence. $\mathrm{H} \varepsilon 1-\mathrm{N} \varepsilon 1$ amino groups from tryptophanes are labeled with an asterisk (*). Also labelled with an asterisk are the assigned amide groups from glutamine and asparagine side chains, which are in addition outlined with horizontal lines. 


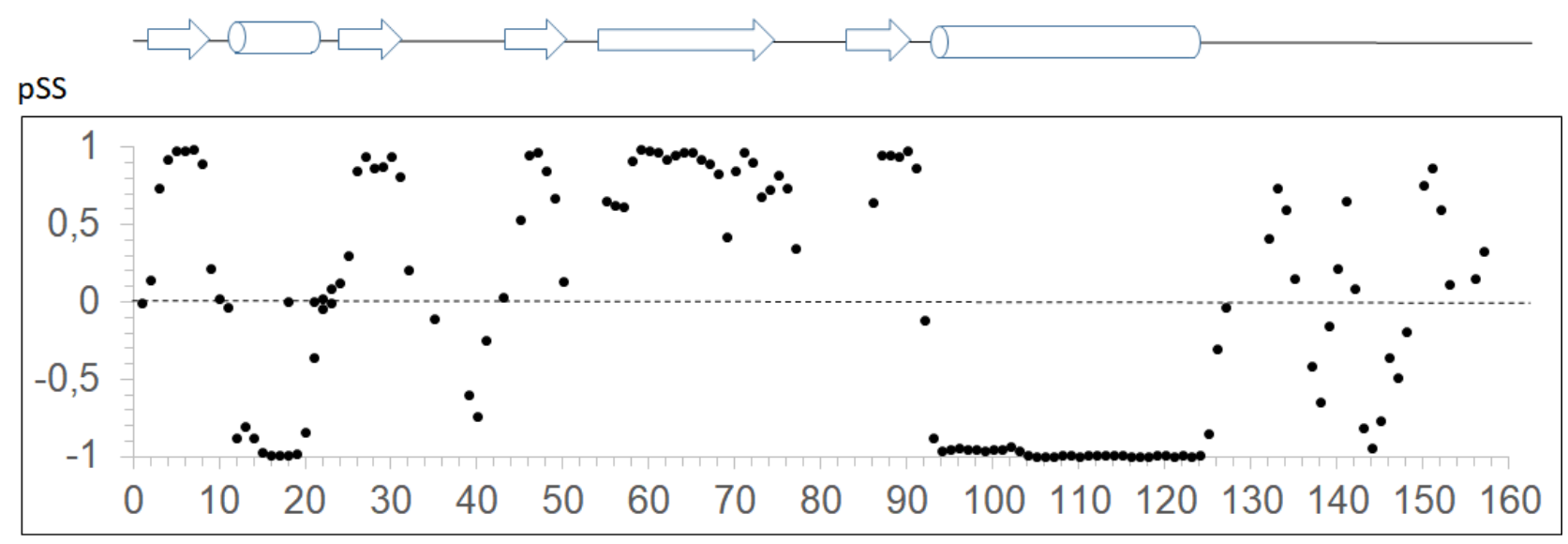

residue

Fig. 2. The secondary structure propensities pSS of the P1 protein derived from TALOS-N on the basis of the chemical shifts of $\mathrm{H}^{\alpha},{ }^{15} \mathrm{~N}, \mathrm{C} \alpha, \mathrm{C} \beta$ and $\mathrm{C}^{\prime}$ atoms (Shen and Bax, 2013). Positive and negative values stand for $\beta$-sheet and $\alpha$-helice predictions respectively. The predicted secondary structures are schematized above.

\section{References}

Ding, S.-W., and Voinnet, O. (2007). Antiviral Immunity Directed by Small RNAs. Cell 130, 413-426.

Gillet, F.-X., Cattoni, D.I., Petiot-Bécard, S., Delalande, F., Poignavent, V., Brizard, J.-P., Bessin, Y., Dorsselaer, A. Van, Declerck, N., Sanglier-Cianférani, S., et al. (2013). The RYMV-Encoded Viral Suppressor of RNA Silencing P1 Is a Zinc-Binding Protein with Redox-Dependent Flexibility. J. Mol. Biol. $425,2423-2435$.

Johnson, B.A., and Blevins, R.A. (1994). NMR View: A computer program for the visualization and analysis of NMR data. J. Biomol. NMR 4, 603-614.

Pons, J.-L., Malliavin, T., and Delsuc, M. (1996). Gifa V. 4: A complete package for NMR data set processing. J. Biomol. NMR 8.

Shen, Y., and Bax, A. (2013). Protein backbone and sidechain torsion angles predicted from NMR chemical 
shifts using artificial neural networks. J. Biomol. NMR 56, 227-241.

Siré, C., Bangratz-Reyser, M., Fargette, D., and Brugidou, C. (2008). Genetic diversity and silencing suppression effects of Rice yellow mottle virus and the P1 protein. Virol. J. 5, 55.

Song, L., Gao, S., Jiang, W., Chen, S., Liu, Y., Zhou, L., and Huang, W. (2011). Silencing suppressors: viral weapons for countering host cell defenses. Protein Cell 2, 273-281. 